\title{
APPLICABILITY OF THE DEA METHOD ON THE TRANSPORT UNDERTAKINGS IN SELECTED REGIONS
}

With respect to achieving the economic goals within ordering of the suitable public transport system it is currently necessary that the economic indicators which contribute to the amount of a provable loss be evaluated rationally. The authors, therefore, will use the DEA method to efficiently assess the economic situation of the specific transport company to find out whether its business is economically attractive. At the same time, the involved companies will be compared with respect to their economically attractive behaviour. The article is based on the public domain information - economic indicators which the undertakings are obliged to publish by law. Despite this fact, it can be concluded that the source data are suitable for the analysis of economic health of a particular transport company.

Keywords: Input-oriented BCC model, transport companies, the DEA method, the constant revenue of scale, the variable revenue of scale.

\section{Introduction}

This paper is aimed to ascertain whether the selected transport companies are effective in using their inputs and outputs.

For the evaluation of effectiveness of these entities, the DEA (Data envelopment analysis) will be used; or more precisely, the input-oriented BCC model will be used under the conditions of variable revenue of scale (BCC).

The DEA method is a specialized model tool used especially to assess the effectiveness, performance and productivity of the homogeneous production entities. The selection of these entities was made upon the identical production, i.e. with the same inputs and outputs. This method is aimed to break the entities down into the effective and ineffective ones as well as to recommend reduction or increase in the inputs or outputs.

The DEA-method based models consider the set of admissible options formed by possible combinations of inputs and outputs. For graphic representation, the so-called effective boundary is used, i..e. the entities lying on this effective boundary are considered effective. Otherwise, they are considered ineffective and the changes thereof need to be proposed.

The CCR model maximizes the rate of effectiveness of the evaluated entity as a quotient of weighted outputs and weighted inputs on condition that the rates of effectiveness of other entities are less than or equal to one. The input-oriented CCR model focuses on such an amount of inputs which are consequently evaluated by this model. The model recommends such changes so that the ineffective entity becomes the effective one. At the same time, the model foresees the constant revenue of scale; i.e. the change in the amount of inputs will be directly proportional to the change in the output amount. For each entity this model will set individual weights of inputs and outputs to maximize the technical efficiency coefficient.

Certain conditions, however, must be met, namely:

Weights cannot be negative;

When using this set of weights for all entities, no coefficient of the technical efficiency must be greater than one.

The input-oriented BCC model is the modification of the previous model CCR. This model already takes into consideration the variable revenue of scale, i.e. increasing, decreasing or constant revenue. It foresees the variable, in certain parts linear revenue of scale and can evaluate the efficiency of entities for the generally non-constant output of scale [1 and 2].

Table 1 contains the basic input data to evaluate the economic health of the specific transport company. For the evaluation purposes, the regional towns without a specific traffic (except for Prague and Brno) were selected [3 - 5].

Table 2 contains the values recommended by the DEA method so that the management of the specific transport company is effective, i.e. the company effectively uses its income to perform traffic services. To take the saving measures, it is appropriate to consider the modification of those inputs which do not have a direct effect on the traffic services, i.e. they will concern only

\footnotetext{
* ${ }^{1}$ Rudolf Kampf, ${ }^{1}$ Jiri Cejka, ${ }^{2}$ Martin Telecky

${ }^{1}$ Institute of Technology and Business in Ceske Budejovice, Czech Republic

${ }^{2}$ Faculty of Economics, South Bohemia University in Ceske Budejovice

E-mail: kampf@mail.vstecb.cz; telecm00@jcu.cz
} 


\section{COMMNICOIIONS}

the modification of the scope of travelled kilometres. Here, the effective tool can be the modification of employment in the contex of modification of the number of vehicles (better distribution of vehicles throughout the day - optimization of circulations and the related optimization of the number of employees - optimization of shifts). The appropriate tool is also the modification of sales from the transportation activity. However, with respect to the current issue, i.e. the massive growth of private motor vehicle transport,

Basic input data of selected transport companies

Basic input data of selected transport companies
\begin{tabular}{|l|c|c|c|c|c|c|c|c|}
\hline & Number of employees & Personnel costs & Cost of sales & $\begin{array}{c}\text { Travelled kilometres in } \\
\text { relation to the specific route }\end{array}$ & Vehicle - kilometres & Number of vehicles & Sales & Transported passengers \\
\hline Ceske Budejovice & 398 & 178399000 & 117146000 & 564776000 & 5651000 & 139 & 123462000 & 38541000 \\
\hline Hradec Kralove & 385 & 155784000 & 112194000 & 475524000 & 5950000 & 126 & 118345000 & 34106000 \\
\hline Chomutov - Jirkov & 239 & 98824000 & 103313000 & 172550000 & 1825000 & 47 & 47432000 & 5102000 \\
\hline Jihlava & 175 & 70657000 & 31579000 & 212255000 & 3032000 & 63 & 47867000 & 13777000 \\
\hline Karlovy Vary & 258 & 109810000 & 78809000 & 225242000 & 2584000 & 61 & 58868000 & 9587000 \\
\hline Liberec & 390 & 152472000 & 130418000 & 680462000 & 7755000 & 212 & 195909000 & 42045000 \\
\hline Most - Litvinov & 446 & 175507000 & 145362000 & 419405000 & 4512000 & 138 & 103496000 & 27420000 \\
\hline Olomouc & 438 & 175092000 & 138433000 & 651153000 & 6196000 & 150 & 146783000 & 52193000 \\
\hline Pardubice & 404 & 162308000 & 85734000 & 557912000 & 5730000 & 129 & 117220000 & 25919000 \\
\hline Teplice & 263 & 107571000 & 109808000 & 299597000 & 5658000 & 130 & 95164000 & 14843000 \\
\hline Usti nad Labem & 484 & 205627000 & 145958000 & 733999000 & 7266000 & 150 & 186476000 & 43162000 \\
\hline Zlin - Otrokovice & 331 & 129335000 & 77076000 & 451512000 & 4824000 & 95 & 117620000 & 31866000 \\
\hline
\end{tabular}

Source: Authors

Recommended values as per the input-oriented BCC model

Table 2

\begin{tabular}{|c|c|c|c|c|c|c|c|c|}
\hline & Number of employees & Personnel costs & Cost of sales & \begin{tabular}{|c|} 
Travelled kilometres in \\
relation to the specific route
\end{tabular} & Vehicle - kilometres & Number of vehicles & Sales & Transported passengers \\
\hline Ceske Budejovice & 365 & 144884774 & 102826113 & 513193026 & 5188460 & 115 & 123462000 & 38541000 \\
\hline Hradec Kralove & 339 & 133356942 & 84354747 & 470012254 & 4942745 & 102 & 118345000 & 34106000 \\
\hline Chomutov - Jirkov & 239 & 98824000 & 103313000 & 172550000 & 1825000 & 47 & 47432000 & 5102000 \\
\hline Jihlava & 175 & 70657000 & 31579000 & 212255000 & 3032000 & 63 & 47867000 & 13777000 \\
\hline Karlovy Vary & 258 & 109810000 & 78809000 & 225242000 & 2584000 & 61 & 58868000 & 9587000 \\
\hline Liberec & 390 & 152472000 & 130418000 & 680462000 & 7755000 & 212 & 195909000 & 42045000 \\
\hline Most - Litvinov & 310 & 122156819 & 79365839 & 400970253 & 4313677 & 88 & 103496000 & 27420000 \\
\hline Olomouc & 438 & 175092000 & 138433000 & 651153000 & 6196000 & 150 & 146783000 & 52193000 \\
\hline Pardubice & 330 & 128998510 & 76815097 & 450139976 & 4813724 & 95 & 117220000 & 31762268 \\
\hline Teplice & 263 & 107571000 & 109808000 & 299597000 & 5658000 & 130 & 95164000 & 14843000 \\
\hline Usti nad Labem & 484 & 205627000 & 145958000 & 733999000 & 7266000 & 150 & 186476000 & 43162000 \\
\hline Zlin - Otrokovice & 331 & 129335000 & 77076000 & 451512000 & 4824000 & 95 & 117620000 & 31866000 \\
\hline
\end{tabular}

Source: Authors

Total evaluation as per the input-oriented BCC model

Table 3

\begin{tabular}{|l|c|c|}
\hline \multicolumn{3}{|c|}{ Input - oriented BCC model BCC } \\
\hline Transport undertaking & Percentage & Effectiveness evaluation \\
\hline Chomutov - Jirkov & $100 \%$ & effective \\
\hline Hradec Kralove & $98,80 \%$ & ineffective \\
\hline Jihlava & $100 \%$ & effective \\
\hline Karlovy Vary & $100 \%$ & effective \\
\hline Liberec & $100 \%$ & effective \\
\hline Most - Litvinov & $95,60 \%$ & ineffective \\
\hline Olomouc & $100 \%$ & effective \\
\hline Pardubice & $89,60 \%$ & ineffective \\
\hline Teplice & $100 \%$ & effective \\
\hline Zlin - Otrokovice & $100 \%$ & effective \\
\hline Ceské Budejovice & $91,80 \%$ & ineffective \\
\hline Usti nad Labem & $100 \%$ & effective \\
\hline
\end{tabular}

Source: Authors

Recommended percentage changes as per the input-oriented BCC model

Table 4

\begin{tabular}{|c|c|c|c|c|c|c|c|c|}
\hline & Number of employees & Personnel costs & Cost of sales & \begin{tabular}{|c|} 
Travelled kilometres in \\
relation to the specific route
\end{tabular} & Vehicle - kilometres & Number of vehicles & Sales & Transported passengers \\
\hline Ceske Budejovice & $-8,19 \%$ & $-18,79 \%$ & $-12,22 \%$ & $-9,13 \%$ & $-8,19 \%$ & $-17,20 \%$ & $0,00 \%$ & $0,00 \%$ \\
\hline Hradec Kralove & $-11,86 \%$ & $-14,40 \%$ & $-24,81 \%$ & $-1,16 \%$ & $-16,93 \%$ & $-19,03 \%$ & $0,00 \%$ & $0,00 \%$ \\
\hline Chomutov - Jirkov & $0 \%$ & $0 \%$ & $0 \%$ & $0 \%$ & $0 \%$ & $0 \%$ & $0 \%$ & $0 \%$ \\
\hline Jihlava & $0 \%$ & $0 \%$ & $0 \%$ & $0 \%$ & $0 \%$ & $0 \%$ & $0 \%$ & $0 \%$ \\
\hline Karlovy Vary & $0 \%$ & $0 \%$ & $0 \%$ & $0 \%$ & $0 \%$ & $0 \%$ & $0 \%$ & $0 \%$ \\
\hline Liberec & $0 \%$ & $0 \%$ & $0 \%$ & $0 \%$ & $0 \%$ & $0 \%$ & $0 \%$ & $0 \%$ \\
\hline Most - Litvinov & $-30,51 \%$ & $-30,40 \%$ & $-45,40 \%$ & $-4,40 \%$ & $-4,40 \%$ & $-36,47 \%$ & $0,00 \%$ & $0,00 \%$ \\
\hline Olomouc & $0 \%$ & $0 \%$ & $0 \%$ & $0 \%$ & $0 \%$ & $0 \%$ & $0 \%$ & $0 \%$ \\
\hline Pardubice & $-18,29 \%$ & $-20,52 \%$ & $-10,40 \%$ & $-19,32 \%$ & $-15,99 \%$ & $-26,50 \%$ & $0,00 \%$ & $22,54 \%$ \\
\hline Teplice & $0 \%$ & $0 \%$ & $0 \%$ & $0 \%$ & $0 \%$ & $0 \%$ & $0 \%$ & $0 \%$ \\
\hline Usti nad Labem & $0 \%$ & $0 \%$ & $0 \%$ & $0 \%$ & $0 \%$ & $0 \%$ & $0 \%$ & $0 \%$ \\
\hline Zlin-Otrokovice & $0 \%$ & $0 \%$ & $0 \%$ & $0 \%$ & $0 \%$ & $0 \%$ & $0 \%$ & $0 \%$ \\
\hline
\end{tabular}

Source: Authors 
this point depends on the promoter's decision on how the urban traffic will be promoted. This aspect is not directly depending on the transport company. With respect to this fact all values of the modification of sales are zero!!! The results of recommended modifications are listed in Table 4 [6, 7, 8 and 9].

\section{Results}

Table 3 shows that the transport companies in the towns of Chomutov - Jirkov, Jihlava, Karlovy Vary, Liberec, Olomouc, Teplice, Zlin - Otrokovice and Usti nad Labem are the effective entities, i.e. the model entities for the ineffective transport undertakings. Based on the model entities, the \% change is recommended for the ineffective entities to make them effective. For the needs of the specific percentage changes, the inputoriented BCC model has been proposed (i.e. minimization of the costs under the conditions of maintaining the same volume of outputs (sales, number of transported passengers). The transport companies marked in blue (Table 4) are ineffective.

The transport company in Pardubice is the least effective and, therefore, the result is not only the input change but also the output change. To achieve higher effectiveness, it is recommended to increase the number of transported passengers by $22.54 \%$, i.e. by $5,843,268$ transported passengers and, at the same time, to reduce the number of employed vehicles by $26.5 \%$. It follows that the time interval should be increased by a few minutes and the number of links should be reduced or cancelled.

In case of the Most - Litvinov transport company, nearly $40 \%$ changes are recommended for some inputs, however, this recommended change is practically unreal. The prerequisite would be reduction of some inputs if the situation allowed so. The highest and the most recommended change is the cost of sales which includes, but is not limited to, the consumption of material and services. It is, therefore, appropriate to find a more effective method for the management of material and other items. Personnel costs represent the next group of recommended changes. Here, it is necessary to distinguish the wages of the drivers, clerical employees, managers and other staff. It is advised to decrease the salaries of senior managers, however, the wages of drivers should be maintained on the same level.
The transport company in Ceske Budejovice is the second most ineffective entity. The biggest change is foreseen in the personnel cost item. This case is identical with the transport company in Most - Litvinov. The next important item to be changed is the number of employees which is closely related to the change in the number of employed vehicles. The cost of sales concern all ineffective entities and it is generally recommended to find more appropriate methods of use of materials and other items.

The transport company in Hradec Králové should also shift its focus on the cost of sales. Reduction of the number of employees and the number of vehicles concern all transport undertakings. Of all ineffective transport companies, the required change of the personnel costs is, however, the lowest. The same also applies to the travelled kilometres in relation to the specific route [10 - 14].

\section{Conclusion}

Based on the above table it can be concluded that the cost of sales of selected transport companies require the necessary changes. The task is to find an appropriate way how to manage the cost of sales items.

The input-oriented BCC model where only the minimization of inputs was applied while maintaining the same outputs (this rule was exceptionally breached in case of the Pardubice transportation company) is just an indicative model. For more detail recommended changes it would be desirable to break down some cost items. Another factor for evaluating the transport undertakings is the verification of the accounting data quality, i.e. quantitative and qualitative data.

The DEA method focuses on a few models: the CCR and BCC models, which evaluate effectiveness of the entities using the set parameters in terms of constant revenue of scale and variable revenue of scale. The goal is to determine the preference of transport companies, i.e. if they want to expect the increase (maximization) in outputs or decrease (minimization) in inputs. Each of the applied models will evaluate the effectiveness of entities with the recommended different changes [15 - 19].

\section{References}

[1] FIALA, P.: Modeling and Analysis of Production Systems, $1^{\text {st }}$ ed., Prague : Professional Publishing, 2002. 260 p. ISBN 80-86419-19-3.

[2] HINDLS, R. et al.: Statistics for Economists, 7. ed., Prague : Professional Publishing, 2006. 420 p. ISBN 80-86946-16-9.

[3] JABLONSKY, J., DLOUHY, M.: Models of Assessing the Effectiveness of Production Units, $1^{\text {st }}$ ed., Prague: Professional Publishing, 2004. 184 p. ISBN 80-86419-49-5.

[4] MAJERCAKOVA, E., MAJERCAK, P.: Application of Clarke-Wright Method for Solving Routing Problem in Distribution Logistics, Logi - Sc. J. on Transport and Logistics, vol. 6, No. 1, 2015, pp. 90-99. ISSN 1804-3216. 
[5] BROZOVA, H., HOUSKA, M., SUBRT, T.: Models for Multi-criteria Decision Making, $1^{\text {st }}$ ed., Prague : Czech University of Life Sciences, 2003, 178 p. ISBN 80-213-1019-7.

[6] FEDORKO, G., HUSAKOVA, N., DUDAS, G.: Design of Allocation of New Technological Equipment within the Frame of Production Process in Company Getrag Ford Transmissions Slovakia, Acta Montanistica Slovaca, vol. 15, 2010, pp. 14-22.

[7] DROZDZIEL, P., KOMSTA, H., KRZYWONOS, L.: An Analysis of Costs of Vehicle Repairs in a Transportation Company, Part II., Transport Problems, vol. 7, No. 4, 2012, pp. 7-11. ISSN 1896-0596.

[8] KUBASAKOVA, I., KAMPF, R., STOPKA, O.: Logistics Information and Communication Technology, Communications Scientific Letters of the University of Zilina, vol. 16, No. 2, 2014, pp. 9-13. ISSN 1335-4205.

[9] STOPKA, O., SIMKOVA, I., KONECNY, V.: The Quality of Service in the Public Transport and Shipping Industry, Nase More, vol. 62, 2015, pp. 126-130. ISSN 0469-6255. doi: 10.17818/NM/2015/SI7.

[10] FAZEKAS, M., SULGAN, M., LISCAK, S.: Electronic Road Toll Systems in Slovakia and a Country Selected from Central Europe. Transport Problems, vol. 8, No. 4, 2013, pp. 35-44. ISSN 1896-0596.

[11] FRIEDMAN, D.: Price Theory: An Intermediate Text. [s.1.]: [s.n.], 1986, 1990. http://www.daviddfriedman.com/Academic/Price Theory/PThy_ToC.html. Chapter 15 Economic Efficiency, 21 p.7

[12] EMROUZNEJAD, A.: Ali Emrouznejad's DEA HomePage [online]. c1995-2001 [cit. 2015-10-20]. Dostupny z WWW: <http://www. deazone.com/>.8

[13] BRUMERCIK, F., KRZYWONOS, L.: Integrated Transportation System Simulation. Logi - Sc. J. on Transport and Logistics, vol. 4, No. 2, 2013, pp. 05-10. ISSN 1804-3216.9

[14] DROZDZIEL, P., KRZYWONOS, L.: The Estimation of the Reliability of the First Daily Diesel Engine Start-Up During its Operation in the Vehicle. Eksploatacja i Niezawodnosc - Maintenance and Reliability, vol. 41, No. 1, 2009, pp. 4-10. ISSN 1507-2711.

[15] SIMKOVA, I., KONECNY, V., LISCAK, S., STOPKA, O.: Measuring the Quality Impacts on the Performance in Transport Company, Transport Problems, vol. 10, No. 3, 2015, pp. 113-124. ISSN 1896-0596.

[16] DROZDZIEL, P., KOMSTA, H., KRZYWONOS, L.: An Analysis of Costs of Vehicle Repairs in a Transportation Company, Part I. Transport Problems, vol. 7, No. 3, 2012, pp. 67-75. ISSN 1896-0596.

[17] KRILE, S., ZAGAR D., MARTINOVIC, G.: Better Bandwidth Utilization of Multiple Link Capacities with Mutual Traffic Correlation, Tehnicki vjesnik - Technical Gazette, vol. 16, No. 4, 2009, pp.11-18. ISSN 1330-3651.

[18] CERNA, L., ZITRICKY, V., MATEJKO, P.: Price Calculation in the International Railway Transport of Goods. Logi - Sc. J. on Transport and Logistics, vol. 4, No. 2, 2013, pp. 11-27. ISSN 1804-3216.

[19] ROZIC, T., FIOLIC, M., BACURA, M.: The Logistics Concept of Optimized Retro-Reflection Dynamic Test of Road Markings on the Roads in the Republic of Croatia. Logi - Sc. J. on Transport and Logistics, vol. 3, No. 2, 2012, pp. 128-135. ISSN 1804-3216. 